\title{
The evolving role of tiotropium in asthma
}

This article was published in the following Dove Press journal:

Journal of Asthma and Allergy

14 August 2017

Number of times this article has been viewed

\author{
Emma R Mclvor' \\ R Andrew Mclvor ${ }^{2}$ \\ 'Queen's University, Belfast, UK; \\ ${ }^{2}$ Department of Medicine, McMaster \\ University, Firestone Institute for \\ Respiratory Health, Hamilton, \\ Ontario, Canada
}

\begin{abstract}
Tiotropium is a long-acting muscarinic antagonist (LAMA) that exerts its bronchodilatory effect by blocking endogenous acetylcholine receptors in the airways. Its safety and efficacy are well established for the treatment of COPD, and it is now being recognized for its role in improving lung function and control in asthma. This review discusses the evolving role of tiotropium delivered by the Respimat ${ }^{\circledR}$ in patients across the range of asthma severities and ages, and provides an overview of safety and efficacy data. Tiotropium is the only LAMA currently approved for the treatment of asthma, and evidence from a large-scale clinical trial program, including several Phase III studies in adults, has demonstrated that tiotropium improves lung function and asthma control, with a safety profile comparable with that of placebo. Clinical trials in adolescent patients (aged 12-17 years) have also shown improvements in lung function and trends toward improved asthma control. Of note, the efficacy and safety profiles are consistent regardless of baseline characteristics and phenotype. Given the large and growing body of evidence, it is likely that as clinical experience with tiotropium increases, this treatment may possibly emerge as the key choice for add-on therapy to inhaled corticosteroids/long-acting $\beta_{2}$-agonists, and in patients who do not tolerate long-acting bronchodilators or other medications, in the future.
\end{abstract}

Keywords: tiotropium, anticholinergics, asthma, efficacy

\section{Introduction}

Asthma continues to be a challenging disease, with increasing prevalence worldwide, ${ }^{1}$ and it is estimated that by 2025,400 million people will be affected. ${ }^{2}$ Asthma is the most common chronic childhood disease ${ }^{3}$ and occurs in countries worldwide regardless of their development status.

The Global Initiative for Asthma (GINA) strategy recommends a stepwise approach in the treatment of asthma, building on a base of inhaled corticosteroids (ICS) to achieve asthma control and reduce future risk. ${ }^{1}$ In the UK, it is estimated that $\sim 65 \%$ of patients being treated with at least an ICS with a long-acting $\beta_{2}$-agonist (LABA) (GINA Step 3) remain uncontrolled. ${ }^{4}$ Thus, there is an ongoing unmet need for improvements in asthma management for patients at GINA Steps 3 and 4, which could be met by effective addons to ICS/LABA. Recent attention in asthma management has focused on biologic treatments for patients with poorly controlled allergic asthma (GINA Step 5). These treatments have proved promising but require specific biomarker analysis to ensure correct patient selection. ${ }^{5}$ Tiotropium, an anticholinergic treatment, is included in the guidelines as an add-on therapeutic option at GINA Steps 4 and 5 in patients with a history of asthma exacerbations. ${ }^{1}$
Correspondence: R Andrew Mclvor T2I 25 FIRH, St Joseph's Healthcare, 50 Charlton Ave East, Hamilton, L8N 4A6 Ontario, Canada Tel + I 905522 II 55 Ext 35872 Email amcivor@stjosham.on.ca 
This review discusses the evolving use of tiotropium in patients across a range of asthma severities and provides an overview of safety and efficacy data. Respimat ${ }^{\circledR}$ is the device with which tiotropium is licensed for the treatment of asthma and with which all the below data were generated; but for brevity hereafter will be referred to as tiotropium.

\section{Mechanism of action for anticholinergic treatments}

Acetylcholine plays a key role in the pathophysiology of asthma by increasing cholinergic tone and thereby driving bronchial smooth muscle contraction. ${ }^{6}$ Tiotropium, a longacting muscarinic antagonist (LAMA), exerts its bronchodilatory effect by blocking endogenous acetylcholine receptors in the airways. ${ }^{7}$ Although tiotropium does not display selectivity for specific muscarinic receptors, it acts mainly on the M3 anticholinergic receptors located in the airways to produce smooth muscle relaxation. Tiotropium dissociates slowly from the M1 and M3 anticholinergic receptors, making it longer acting than ipratropium, ${ }^{8}$ a short-acting anticholinergic treatment that offers a potential alternative to short-acting $\beta_{2}$-agonists (SABAs) for the relief of asthma symptoms. ${ }^{1}$ Ipratropium has been used in the treatment of asthma for many years, but is considered less effective than shortacting $\beta_{2}$-agonists. ${ }^{9}$ Muscarinic antagonists, both long- and short-acting, therefore, facilitate bronchodilation in a way that is both complementary and different to LABAs/SABAs.

\section{Evidence of tiotropium efficacy across a range of asthma severities}

Tiotropium has been indicated for the treatment of COPD for over 10 years and is now licensed for use in asthma. This is currently the only LAMA approved for the treatment of patients with asthma ${ }^{10}$ in the EU for patients aged $\geq 18$ years, in Japan for patients aged $\geq 15$ years and in the USA for patients aged $\geq 6$, and is currently undergoing regulatory review in a number of other countries. The label varies by country, so it is important to refer to the local product information for details.

The safety and efficacy profile of tiotropium has been established in adult patients with mild, moderate and severe asthma in a comprehensive Phase III study program. Inclusion criteria were broad and patients were required to have a documented history of symptomatic asthma. Patients with a significant disease other than asthma and patients with known hypersensitivity to anticholinergic drugs were excluded. In total, six of the adult Phase III studies investigated the efficacy and safety of once-daily tiotropium $5 \mu \mathrm{g}$ (given as two puffs once daily) versus placebo added onto low- or high-dose ICS (with or without LABA) (Table 1). Four of these studies also investigated the use of tiotropium at the lower dose of $2.5 \mu \mathrm{g}$ (given as two puffs once daily). In studies with $2.5 \mu \mathrm{g}$ dose as an endpoint, both doses of tiotropium had a significantly greater improvement in forced expiratory volume in 1 second in first 3 hours of dosing $\left(\mathrm{FEV}_{1(0-3 \mathrm{~h})}\right)$ compared with placebo. Furthermore, in a pooled safety analysis of the adult data, the proportion of patients reporting adverse events, including serious adverse events, was comparable between treatment groups. ${ }^{11}$ The first Phase III study conducted was the PrimoTinAasthma ${ }^{\circledR}$ study, which comprised two replicate, randomized controlled trials in adults with severe uncontrolled asthma. Tiotropium $(5 \mu \mathrm{g})$ or placebo were added to high-dose ICS ( $\geq 800 \mu \mathrm{g}$ budesonide or equivalent/day) plus LABA once daily for 48 weeks. ${ }^{12}$ This study showed that in patients with uncontrolled asthma (despite treatment with ICS/LABA), the addition of tiotropium significantly increased the time to first exacerbation and provided a modest sustained bronchodilation. ${ }^{12}$ A second Phase III study, MezzoTinA-asthma ${ }^{\circledR}$, also comprised two replicate, randomized, double-blind, placebo-controlled active comparator trials in adult patients with moderate persistent asthma. Tiotropium ( 5 or $2.5 \mu \mathrm{g}$ ), placebo once-daily or twice-daily salmeterol $50 \mu \mathrm{g}$ were added to at least medium-dose ICS (400-800 $\mu \mathrm{g} /$ day). In this study, once-daily tiotropium add-on to medium-dose ICS was shown to reduce airflow obstruction and improve asthma control. The pattern of response observed was similar to that of salmeterol and it was concluded that tiotropium is a safe and effective bronchodilator and an alternative to salmeterol in this patient population. ${ }^{13} \mathrm{~A}$ further study, GraziaTinA-asthma ${ }^{\circledR}$, was conducted in adults with mild persistent asthma. Tiotropium ( 5 or $2.5 \mu \mathrm{g}$ ) and placebo were added to low- and medium-dose ICS (200-400 $\mu \mathrm{g} /$ day). This study again showed that once-daily tiotropium was an efficacious bronchodilator and that safety and tolerability were comparable with placebo. ${ }^{14}$

Overall, these studies demonstrate the efficacy and tolerability of tiotropium in adults with a range of asthma severities. The data further highlight the consideration of once-daily tiotropium as an add-on therapy to improve lung function and asthma control, regardless of disease severity. In support three systematic reviews published by the Cochrane Library have also found that tiotropium serves as an effective bronchodilator across varying severities of asthma in patients who remain symptomatic on at least ICS, particularly as addon to ICS/LABA therapy. ${ }^{15-18}$ 
Table I Key results of Phase III adult asthma studies with tiotropium Respimat ${ }^{\circledR} 5 \mu \mathrm{g}$

\begin{tabular}{|c|c|c|c|c|c|}
\hline Study name & $\begin{array}{l}\text { Treatment } \\
\text { duration, } \\
\text { weeks }\end{array}$ & $\mathbf{N}$ & $\begin{array}{l}\text { Primary and key } \\
\text { secondary endpoints }\end{array}$ & Difference from pla & ebo \\
\hline \multirow{4}{*}{$\begin{array}{l}\text { PrimoTinA-asthma }{ }^{\circledR} \\
\text { Severe persistent } \\
\text { asthma }^{37}\end{array}$} & \multirow[t]{4}{*}{48} & \multirow[t]{4}{*}{912} & $\begin{array}{l}\text { Peak FEV }{ }_{1} \text {, } \\
\text { Week 24, mean }(\mathrm{Cl}) \mathrm{mL}\end{array}$ & $\begin{array}{l}86(20,152)(P=0.01) \\
\text { Trial I }\end{array}$ & $\begin{array}{l}\text { Trial } 2 \\
\text { I54 (9I, } 217)(P<0.00 \mid)\end{array}$ \\
\hline & & & $\begin{array}{l}\text { Trough } \mathrm{FEV}_{1} \text {, } \\
\text { Week 24, mean }(\mathrm{Cl}) \mathrm{mL}\end{array}$ & $\begin{array}{l}88(27,149)(P=0.01) \\
\text { Trial I }\end{array}$ & $\begin{array}{l}\text { Trial } 2 \\
\text { III }(53,169)(P<0.00 I)\end{array}$ \\
\hline & & & Time to first severe exacerbation & \multicolumn{2}{|c|}{$\begin{array}{l}-0.2(P=0.003) \text { Trial } 2 \\
21 \% \text { reduction in risk (HR 0.79; } 95 \% \text { Cl: } 0.62,1.00 ; \\
P=0.03)\end{array}$} \\
\hline & & & ACQ-7, adjusted mean score & NS & \\
\hline \multirow{3}{*}{$\begin{array}{l}\text { MezzoTinA-asthma }{ }^{\circledR} \\
\text { Moderate persistent } \\
\text { asthma }^{38}\end{array}$} & \multirow[t]{3}{*}{24} & \multirow[t]{3}{*}{2103} & $\begin{array}{l}\text { Peak } \mathrm{FEV}_{1} \\
\text { mean }(\mathrm{Cl}) \mathrm{mL}\end{array}$ & $\begin{array}{l}\text { I98 }(142,253) \\
(P<0.0001) \text { Trial I }\end{array}$ & $\begin{array}{l}(P<0.0001) \text { Trial } 2 \\
169(116,222)\end{array}$ \\
\hline & & & $\begin{array}{l}\text { Peak FVC, } \\
\text { mean }(\mathrm{Cl}) \mathrm{mL}\end{array}$ & $\begin{array}{l}02(42,162) \\
(P=0.0008) \text { Trial I }\end{array}$ & $\begin{array}{l}(P=0.003 \mathrm{I}) \text { Trial } 2 \\
89(30,147)\end{array}$ \\
\hline & & & ACQ-7, adjusted mean score & \multicolumn{2}{|c|}{$-0.12(S D 0.04 ; P=0.0084)$} \\
\hline \multirow{3}{*}{$\begin{array}{l}\text { GraziaTinA-asthma }^{\circledR} \\
\text { Mild persistent } \\
\text { asthma } \\
\end{array}$} & \multirow[t]{3}{*}{12} & \multirow[t]{3}{*}{465} & $\begin{array}{l}\text { Peak FEV } \\
\text { Week } 12 \text { mean }(\mathrm{Cl}) \mathrm{mL}\end{array}$ & \multicolumn{2}{|c|}{$128(57,199)(P<0.00 \mathrm{I})$} \\
\hline & & & $\begin{array}{l}\text { Trough } \mathrm{FEV}_{1}, \\
\text { Week } 12 \text { mean }(\mathrm{Cl}) \mathrm{mL}\end{array}$ & \multicolumn{2}{|l|}{$122(49,194)(P<0.00 \mid)$} \\
\hline & & & ACQ-7 total score, Week 12 & \multicolumn{2}{|c|}{$0.014(-118,0.146)(P=0.83)$} \\
\hline \multirow[t]{2}{*}{$\begin{array}{l}\text { CadenTinA-asthma }^{\circledR} \\
\text { Symptomatic asthma } \\
\text { Se }^{40}\end{array}$} & \multirow[t]{2}{*}{52} & \multirow[t]{2}{*}{285} & Long-term safety & \multicolumn{2}{|c|}{$\begin{array}{l}\text { Incidence of patients reporting AEs was } \\
\text { similar across treatment groups }\end{array}$} \\
\hline & & & $\begin{array}{l}\text { Trough } \mathrm{FEV}_{1}, \\
\text { Week } 52 \text { mean }(\mathrm{Cl}) \mathrm{mL}\end{array}$ & \multicolumn{2}{|c|}{ II $(I 8,207)(P=0.0203)$} \\
\hline
\end{tabular}

Abbreviations: ACQ-7, 7-question asthma control questionnaire; $\mathrm{AE}$, adverse event; $\mathrm{Cl}$, confidence interval; $\mathrm{FEV}_{\text {, }}$, forced expiratory volume in I second; $\mathrm{FVC}$, forced vital capacity; HR, hazard ratio; ICS, inhaled corticosteroids; NS, not significant; SD, standard deviation.

More recent trials have also demonstrated the efficacy and safety of tiotropium in younger age groups. Phase II, randomized, dose-ranging studies of tiotropium at 1.25, 2.5 and $5 \mu \mathrm{g}$ in children aged $6-11$ years $^{19}$ and adolescents aged $12-17$ years ${ }^{20}$ with symptomatic asthma despite maintenance treatment with ICS have demonstrated the efficacy and safety of tiotropium in younger patients, suggesting the potential indication of tiotropium across all age groups. A further five Phase III clinical trials in children with moderate to severe symptomatic asthma have been conducted to assess the efficacy and safety of once-daily tiotropium 2.5 and $5 \mu \mathrm{g}$ versus placebo as add-on therapy to a treatment including ICS (low to high dose) with or without additional controllers (Table 2). ${ }^{21-25}$ In adolescent patients (12-17 years old), the
RubaTinA-asthma ${ }^{\circledR}$ study showed that once-daily tiotropium significantly improved lung function in patients with moderate asthma. Improvement in peak $\mathrm{FEV}_{1(0-3 \mathrm{~h})}$ after dosing at Week 24 was statistically significant with both tiotropium doses compared with placebo: $5 \mu \mathrm{g}$ tiotropium, adjusted mean difference $174 \mathrm{~mL}(95 \% \mathrm{CI}: 76,272 \mathrm{~mL} ; P<0.001) ; 2.5 \mu \mathrm{g}$ tiotropium, $134 \mathrm{~mL}(95 \% \mathrm{CI}: 34,234 \mathrm{~mL} ; P<0.01) .{ }^{25}$ In the same age group but in patients with more severe asthma, PensieTinA-asthma ${ }^{\circledR}$ study reported that tiotropium $5 \mu$ g provided numerical improvements in peak $\mathrm{FEV}_{1(0-3 \mathrm{~h})}$ compared with placebo ( $90 \mathrm{~mL} ; P=0.104)$ and nominal significant improvements were seen with the $2.5 \mu \mathrm{g}$ dose $(111 \mathrm{~mL} ; P=0.046)$. Although the primary efficacy endpoint was not met, there were positive trends for improvements in lung function and

Table 2 Phase III studies with tiotropium Respimat ${ }^{\circledR}$ in children and adolescents with asthma

\begin{tabular}{|c|c|c|c|c|c|}
\hline Study name & $\begin{array}{l}\text { Patients (asthma severity } \\
\text { and age) }\end{array}$ & $\begin{array}{l}\text { Treatment } \\
\text { duration, weeks }\end{array}$ & Baseline therapy & $\begin{array}{l}N \text { (treatment } \\
\text { group) }\end{array}$ & Study drug \\
\hline RubaTinA-asthma $^{\circledR 41}$ & Moderate persistent 12-17-year-olds & 48 & At least ICS & 259 & Tiotropium \\
\hline PensieTinA-asthma ${ }^{\circledR 42}$ & Severe persistent 12-17-year-olds & 12 & ICS $+\geq \mid$ controller & 257 & Respimat 2.5 \\
\hline CanoTinA-asthma ${ }^{\circledR 43}$ & Moderate persistent 6-II-year-olds & 48 & At least ICS & 270 & and $5 \mu \mathrm{g}$ \\
\hline VivaTinA-asthma ${ }^{\circledR 44}$ & Severe persistent 6-11-year-olds & 12 & At least ICS $/+\geq I$ controller & 262 & \\
\hline NinoTinA-asthma ${ }^{\circledR 45}$ & Persistent $1-5$-year-olds & & At least ICS & 67 & \\
\hline
\end{tabular}

Abbreviation: ICS, inhaled corticosteroids. 
asthma control. ${ }^{24}$ VivaTinA-asthma ${ }^{\circledR}$ and CanoTinA-asthma ${ }^{\circledR}$ were conducted in younger children (aged 6-11 years; Table 2). In VivaTinA-asthma, compared with placebo, tiotropium $5 \mu \mathrm{g}$ add-on therapy significantly improved the primary endpoint, peak $\mathrm{FEV}_{1(0-3 \mathrm{~h})}(139 \mathrm{~mL}$ [95\% CI: 75, $203 ; P<0.001])$ and was well tolerated as an add-on therapy to ICS with other maintenance therapies in children with severe symptomatic asthma. ${ }^{23}$ The CanoTinA-asthma study showed that in children with moderate symptomatic asthma both doses of tiotropium, 5 and $2.5 \mu \mathrm{g}$, significantly improved peak $\mathrm{FEV}_{1(0-3 \mathrm{~h})}$ at Week 24, with adjusted mean differences of 164 and $170 \mathrm{~mL}$ versus placebo, respectively $(P<0.01$ for both comparisons). It also showed that once-daily tiotropium as an add-on to usual maintenance therapy was again considered safe and well tolerated. ${ }^{22}$ Finally, NinoTinA-asthma, the first study to evaluate the efficacy and safety of tiotropium in preschool children (1-5 years old) with persistent asthma on a stable dose of ICS, reported that tiotropium is a welltolerated add-on option and indicated that there may be a reduction in risk of asthma exacerbations reported as adverse events in this trial. ${ }^{21}$

Taken together, the Phase III studies in children, adolescents and adults demonstrate that tiotropium is effective and well tolerated in a diverse range of patient groups. Tiotropium is currently recommended as an alternative add-on treatment option at GINA Steps 4 and 5 in patients $\geq 12$ years of age with a history of exacerbations. ${ }^{1}$ Other add-on therapeutic options are also included in the GINA guidelines; ${ }^{1}$ these are listed in Box 1.

\section{Cost-effectiveness of tiotropium}

With the increasing prevalence of asthma worldwide, there is a need for more affordable and readily accessible therapies, specifically cost-effective add-ons to ICS/LABA. It is thought that $\sim 4 \%$ of people with asthma suffer from true severe refractory disease, ${ }^{26}$ and studies have shown that this subgroup of patients has a disproportionate economic burden, with mean

Box I GINA guideline options for add-on therapy in the management of patients with severe asthma

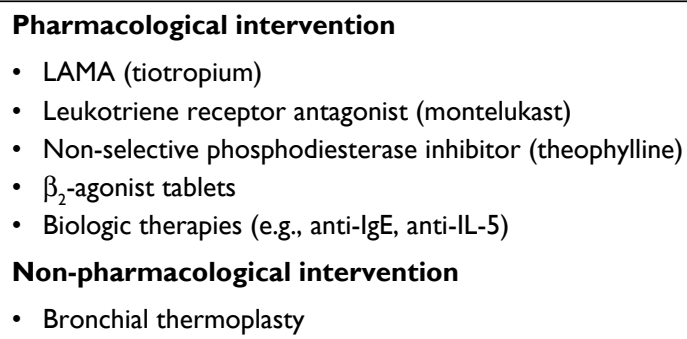

Abbreviations: LAMA, long-acting muscarinic antagonist; GINA,The Global Initiative for Asthma; IgE, immunoglobulin E; IL, interleukin.
UK annual treatment costs reaching between $£ 2,912$ and $£ 4,217$ per patient. ${ }^{27}$ The long-term goal of asthma treatment is to achieve control, in particular on current impairment on a day-to-day basis and to minimize future risk of exacerbations. ${ }^{1}$ Tiotropium has been reported as a cost-effective option for addon therapy. A Markov model to estimate the cost-effectiveness of tiotropium from the perspective of the UK National Health Service was created using data from the PrimoTinA-asthma study. ${ }^{28}$ Add-on tiotropium generated an incremental 0.24 in quality-adjusted life years (QALY) and $£ 5,238$ costs over a lifetime horizon, resulting in an incremental cost-effectiveness ratio of $£ 21,906$ per QALY gained (based on 2012 pricing). It was concluded that in adults with severe asthma, tiotropium provided a cost-effective treatment option if used in combination with high-dose ICS/LABA therapy. Further studies are required to assess the impact that tiotropium has on patients requiring hospitalizations as this could have further implications for cost-effectiveness. Studies examining the cost-effectiveness of tiotropium in relation to biologic treatments, such as omalizumab and mepolizumab, are also required.

\section{Perspectives}

Tiotropium is the only LAMA currently approved for use in asthma and has a considerable database of efficacy and safety across different age groups and severities of asthma. ${ }^{29}$ Given the large and growing body of evidence, it is likely that as clinical experience with tiotropium increases, this treatment may emerge as the key choice for add-on therapy to ICS/LABA. Some studies have shown that patients can develop a tolerance to LABAs, ${ }^{30-32}$ which impairs efficacy in bronchospasm prevention. Tiotropium, therefore, may possibly be considered as the key choice add-on to ICS for LABA-intolerant patients in the future.

In recent years, approaches for the management of severe asthma have included the development of targeted biological therapies for patients with poorly controlled allergic or Type 2 asthma (GINA Step 5). While these treatments have proved promising for use in clinical practice, they are often limited to patients with a particular asthma phenotype, and specific biomarker analysis is required to ensure correct patient selection. ${ }^{5}$ Evidence from a comprehensive clinical trial program with tiotropium has shown it to be a well-tolerated treatment that improves lung function and asthma control in all patient phenotypes and asthma severities studied. A further study by Kerstjens et al reported that tiotropium $5 \mu \mathrm{g}$ improved lung function, reduced risk of exacerbations (time to first severe exacerbation), and improved asthma symptom control independent of immunoglobulin E levels, eosinophil counts, age, gender 
or baseline demographics compared with placebo. ${ }^{33}$ Thus, with no need for biomarker assessment, the evidence suggests tiotropium is quick and easy to incorporate in clinical practice.

The soft-mist inhaler device is easy to use by all age groups and severities of disease, and tiotropium has been shown to be efficacious in pediatric patients with symptomatic asthma. ${ }^{19,22}$ Evidence from a handling study to assess the use of the soft-mist inhaler in children $\geq 5$ years old concluded that it was suitable for children aged 5 years, as well as those aged $<5$ years, although these younger patients are advised to add a valved holding chamber (VHC) to complement its use. ${ }^{34,35}$ A previous in vitro study using throat models of $\sim 5$-year-old children reported that the use of the AeroChamber Plus ${ }^{\circledR}$ Flow-Vu ${ }^{\circledR}$ (Allergan PLC, Dublin, Ireland) VHC with tiotropium Respimat provided optimal dose-to-lung (DTL) in comparison with other VHCs, while minimizing retention at throat level. ${ }^{36}$ In vitro determinations of delivered DTL with the Respimat and VHC serve as a good predictor of the in vivo tiotropium delivery to the lungs of children. A study using mouth-throat models and real-life inhalation profiles of children aged 0-5 years reported that the DTL from the Respimat plus VHC ranged from 5.1\% to $37.1 \%$ depending on age. This corresponded to an in vitro DTL per body mass of $0.031-0.066 \mathrm{~g} / \mathrm{kg}$, which compared well with that of adults $(0.046 \mathrm{~g} / \mathrm{kg}) .{ }^{34}$ These findings suggest that the efficacy of tiotropium treatment in children $0-5$ years would not be negatively impacted by use of a VHC.

One important consideration for the use of tiotropium in asthma is the need for a change in the attitude of clinicians and health care professionals who associate tiotropium solely with the treatment of COPD. With the ever-growing and significant evidence of the efficacy and safety of tiotropium in children, adolescents and adults with asthma, it is possible that this treatment will be a mainstay in the asthma treatment landscape.

\section{Summary}

Tiotropium is a well-tolerated and effective add-on treatment for adults, children and adolescents with uncontrolled symptomatic asthma. The efficacy and safety profiles are consistent regardless of baseline characteristics and phenotype, which makes this treatment an ideal choice in the treatment of asthma. Tiotropium has been shown to be effective in a range of asthma severities, and to be cost-effective as an add-on therapy. Given the large and growing body of evidence, it is likely that as clinical experience with tiotropium increases, this treatment may emerge as the key choice as add-on therapy to ICS/LABA, and possibly as a first-line add-on to ICS in patients who do not tolerate LABA.

\section{Acknowledgments}

Medical writing assistance was provided by Dr Manminder Kaur from MediTech Media, funded by Boehringer Ingelheim. RA McIvor has received honoraria from AstraZeneca, Boehringer Ingelheim, Merck, Novartis, Pfizer, Roche, Teva, Takeda and Trudell for attendance at advisory boards and providing continued medical education (CME).

\section{Disclosure}

RA McIvor is an employee of McMaster University and St Joseph's Healthcare, Hamilton, Ontario. The authors disclose a father/daughter collaboration. The other author reports no conflict of interest in this work.

\section{References}

1. Global Initiative for Asthma. Global Strategy for Asthma Management and Prevention. 2017. Available from http://ginasthma.org/. Accessed July 24, 2017.

2. Masoli M, Fabian D, Holt S, Beasley R, Global Initiative for Asthma (GINA) Program. The global burden of asthma: executive summary of the GINA dissemination committee report. Allergy. 2004;59(5):469-478.

3. World Health Organization. Asthma. fact sheet no.307. Available from: http://www.who.int/mediacentre/factsheets/fs307/en/. Updated 2013. Accessed December 14, 2016.

4. Price D, Mathieson N, Mulgirigama A, et al. P17 the burden of ICS/ LABA-treated asthma patients in the UK adult population. Thorax. 2013;68(Suppl 3):A82.

5. Chang A, Bosse Y. Targeting single molecules in asthma benefits few. Trends Mol Med. 2016;22(11):935-945.

6. Canning BJ. Reflex regulation of airway smooth muscle tone. J Appl Physiol (1985). 2006;101(3):971-985.

7. Goyal M, Jaseja H, Verma N. Increased parasympathetic tone as the underlying cause of asthma: a hypothesis. Med Hypotheses. 2010;74(4): 661-664.

8. Barnes PJ. The pharmacological properties of tiotropium. Chest. 2000;117(Suppl 2):63S-66S.

9. Novelli F, Malagrino L, Dente FL, Paggiaro P. Efficacy of anticholinergic drugs in asthma. Expert Rev Respir Med. 2012;6(3):309-319.

10. Busse WW, Dahl R, Jenkins C, Cruz AA. Long-acting muscarinic antagonists: a potential add-on therapy in the treatment of asthma?. Eur Respir Rev. 2016;25(139):54-64.

11. Dahl R, Engel M, Dusser D, et al. Safety and tolerability of once-daily tiotropium respimat( $(\mathbb{B})$ as add-on to at least inhaled corticosteroids in adult patients with symptomatic asthma: a pooled safety analysis. Respir Med. 2016;118:102-111.

12. Kerstjens HA, Engel M, Dahl R, et al. Tiotropium in asthma poorly controlled with standard combination therapy. NEngl J Med. 2012;367(13): 1198-1207.

13. Kerstjens HA, Moroni-Zentgraf P. Bronchodilator reversibility and cardiac considerations with use of tiotropium. Lancet Respir Med. 2015;3(8):e25-e26.

14. Paggiaro P, Halpin DM, Buhl R, et al. The effect of tiotropium in symptomatic asthma despite low- to medium-dose inhaled corticosteroids: a randomized controlled trial. J Allergy Clin Immunol Pract. 2016;4(1): 104-113. 
15. Anderson DE, Kew KM, Boyter AC. Long-acting muscarinic antagonists (LAMA) added to inhaled corticosteroids (ICS) versus the same dose of ICS alone for adults with asthma. Cochrane Database Syst Rev. 2015;(8):CD011397.

16. Kew KM, Dahri K. Long-acting muscarinic antagonists (LAMA) added to combination long-acting beta2-agonists and inhaled corticosteroids (LABA/ICS) versus LABA/ICS for adults with asthma. Cochrane Database Syst Rev. 2016;(1):CD011721.

17. Kew KM, Evans DJ, Allison DE, Boyter AC. Long-acting muscarinic antagonists (LAMA) added to inhaled corticosteroids (ICS) versus addition of long-acting beta2-agonists (LABA) for adults with asthma. Cochrane Database Syst Rev. 2015;(6):CD011438.

18. Rodrigo GJ, Castro-Rodriguez JA. What is the role of tiotropium in asthma?: a systematic review with meta-analysis. Chest. 2015;147(2): 388-396.

19. Vogelberg C, Moroni-Zentgraf P, Leonaviciute-Klimantaviciene M, et al. A randomised dose-ranging study of tiotropium respimat ${ }^{\mathbb{R}}$ in children with symptomatic asthma despite inhaled corticosteroids. Respir Res. 2015;16:20.

20. Vogelberg C, Engel M, Moroni-Zentgraf P, et al. Tiotropium in asthmatic adolescents symptomatic despite inhaled corticosteroids: a randomised dose-ranging study. Respir Med. 2014;108(9):1268-1276.

21. Schmidt O, Hamelmann E, Vogelberg C, et al. Once-daily tiotropium respimat $^{\mathbb{R}}$ add-on therapy improves lung function in children with moderate symptomatic asthma. Eur Respir J. 2016;48:PA4398.

22. Bisgaard H, Vandewalker M, Graham LM, Moroni-Zentgraf P, Engel M, El Azzi G, et al. Safety of tiotropium in pre-school children with symptomatic persistent asthma. Eur Respir J. 2016; 48: PA315.

23. Szefler SJ, Murphy K, Harper T, et al. A phase III randomized controlled trial of tiotropium add-on therapy in children with severe symptomatic asthma. J Allergy Clin Immunol. Epub 2017 Feb 9.

24. Hamelmann E, Bernstein JA, Vandewalker M, et al. A randomised controlled trial of tiotropium in adolescents with severe symptomatic asthma. Eur Respir J. 2017;49(1):1601100.

25. Hamelmann E, Bateman ED, Vogelberg C, et al. Tiotropium add-on therapy in adolescents with moderate asthma: a 1-year randomized controlled trial. J Allergy Clin Immunol. 2016;138(2):441-450.

26. Slater MG, Pavord ID, Shaw DE. Step 4: stick or twist? a review of asthma therapy. BMJ Open Respir Res. 2016;3(1):e000143.

27. O'Neill S, Sweeney J, Patterson CC, et al. The cost of treating severe refractory asthma in the UK: an economic analysis from the British Thoracic Society difficult asthma registry. Thorax. 2015;70(4): 376-378.

28. Willson J, Bateman ED, Pavord I, Lloyd A, Krivasi T, Esser D. Cost effectiveness of tiotropium in patients with asthma poorly controlled on inhaled glucocorticosteroids and long-acting beta-agonists. Appl Health Econ Health Policy. 2014;12(4):447-459.

29. Halpin DM. Tiotropium in asthma: what is the evidence and how does it fit in? World Allergy Organ J. 2016;9(1):29.

30. Elers J, Strandbygaard U, Pedersen L, Backer V. Daily use of salmeterol causes tolerance to bronchodilation with terbutaline in asthmatic subjects. Open Respir Med J. 2010;4:48-50.
31. Tan KS, Grove A, McLean A, Gnosspelius Y, Hall IP, Lipworth BJ. Systemic corticosteriod rapidly reverses bronchodilator subsensitivity induced by formoterol in asthmatic patients. Am J Respir Crit Care Med. 1997;156(1):28-35.

32. Yates DH, Sussman HS, Shaw MJ, Barnes PJ, Chung KF. Regular formoterol treatment in mild asthma. effect on bronchial responsiveness during and after treatment. Am J Respir Crit Care Med. 1995;152(4 Pt 1):1170-1174.

33. Kerstjens HA, Moroni-Zentgraf P, Tashkin DP, et al. Tiotropium improves lung function, exacerbation rate, and asthma control, independent of baseline characteristics including age, degree of airway obstruction, and allergic status. Respir Med. 2016;117:198-206.

34. Bickmann D, Kamin W, Sharma A, Wachtel H, Moroni-Zentgraf P, Zielen S. In vitro determination of respimat $^{\circledR}$ dose delivery in children: an evaluation based on inhalation flow profiles and mouth-throat models. J Aerosol Med Pulm Drug Deliv. 2016;29(1):76-85.

35. Kamin W, Frank M, Kattenbeck S, Moroni-Zentgraf P, Wachtel H, Zielen S. A handling study to assess use of the respimat ${ }^{\mathbb{B}}$ soft mist ${ }^{\mathrm{TM}}$ inhaler in children under 5 years old. J Aerosol Med Pulm Drug Deliv. 2015;28(5):372-381.

36. Wachtel H, Bickmann D, Breitkreutz J, Langguth P. Can pediatric throat models and air flow profiles improve our dose finding strategy?. Respiratory Drug Delivery. 2010;1:195-204.

37. Kerstjens HA, Engel M, Dahl R, et al. Tiotropium in asthma poorly controlled with standard combination therapy. $N$ Engl J Med. 2012;367:1198-1207.

38. Kerstjens HA, Casale TB, Bleecker ER, et al. Tiotropium or salmeterol as add-on therapy to inhaled corticosteroids for patients with moderate symptomatic asthma: two replicate, double-blind, placebo-controlled, parallel-group, active-comparator, randomised trials. Lancet Respir Med. 2015;3:367-376.

39. Paggiaro P, Halpin DM, Buhl R, et al. The effect of tiotropium in symptomatic asthma despite low- to medium-dose inhaled corticosteroids: a randomized controlled trial. JAllergy Clin Immunol Pract. 2016;4:104-113.

40. Ohta K, Ichinose M, Tohda Y, et al. Long-term once-daily tiotropium respimat $^{\circledR}$ is well tolerated and maintains efficacy over 52 weeks in patients with symptomatic asthma in Japan: a randomised, placebocontrolled study. PLoS One. 2015;10:e0124109.

41. Hamelmann E, Bateman ED, Vogelberg C, et al. Tiotropium add-on therapy in adolescents with moderate asthma: a 1-year randomized controlled trial. J Allergy Clin Immunol. 2016;138:441-450.

42. Hamelmann E, Bernstein JA, Vandewalker M, et al. A randomised controlled trial of tiotropium in adolescents with severe symptomatic asthma. Eur Respir J. 2017;49:1601100.

43. Schmidt O, Hamelmann E, Vogelberg C, et al. Once-daily tiotropium Respimat $^{\circledR}$ add-on therapy improves lung function in children with moderate symptomatic asthma. Eur Respir J. 2016;48:PA4398.

44. Szefler SJ, Murphy K, Harper T,3rd, et al. A phase III randomized controlled trial of tiotropium add-on therapy in children with severe symptomatic asthma. J Allergy Clin Immunol. 2017.

45. Bisgaard H, Vandewalker M, Graham LM, Moroni-Zentgraf P, Engel M, El Azzi G, et al. Safety of tiotropium in pre-school children with symptomatic persistent asthma. Eur Respir J. 2016; 48: PA315.
Journal of Asthma and Allergy

\section{Publish your work in this journal}

The Journal of Asthma and Allergy is an international, peer-reviewed open access journal publishing original research, reports, editorials and commentaries on the following topics: Asthma; Pulmonary physiology; Asthma related clinical health; Clinical immunology and the immunological basis of disease; Pharmacological interventions and new therapies. This journal is included in PubMed. The manuscript management system is completely online and includes a very quick and fair peer-review system, which is all easy to use. Visit http://www. dovepress.com/testimonials.php to read real quotes from published authors. 